\title{
Expression of Heat Shock Protein HSP90 in Genomic-DNA of Chickpea (Cicer arietinum L.) Callus by Heat Shock Treatment
}

\section{Anwaar F AL-Taee*}

Ph.D. Student, Department of Biology, Education College for Pure Sciences, University of Mosul, Iraq

\section{E-mail: anwar.altaee@uomosul.edu.iq}

\section{Dr. Jamella H Rasheed}

Prof. Doctor in Biology, Department of Biology, Education College for Pure Sciences, University of Mosul, Iraq

Email: dr.jamella.h.rasheed@uomosul.edu.iq

\begin{abstract}
:
This study was able to detect of the expression activity of heat shock proteins $H S P 90$ and heat transcription factors HSFs for the first time in callus cultures of chickpea, Cicer arietinum L., that exposed to abiotic shocks, grown on MS medium supplemented with $1.0 \mathrm{mg} \mathrm{L}^{-1}$ naphthalene acetic acid (NAA) and $2.0 \mathrm{mg} \mathrm{L}^{-1}$ benzyl adenine (BA). Heat shock proteins HSPs were constructed for increase of withstand long-term physical shocks, and production of resistant to heat chickpeas plants, this shock was enhancement of tolerance of chickpea callus to abiotic stresses (high - temperatures). Results enhanced the ability of chickpea callus to abiotic stresses bearing and induce of HSF genes to heat shock proteins $H S P 90$ production quickly to removing denatured proteins, avoid apoptosis, thus, supporting tolerance to the sudden action of these shocks. Expression activity of heat shock genes and transcription factors by determined based on polymerase chain reaction $\mathrm{qPCR}$, that explained the gene activity increasing at shocks intensity increased,
\end{abstract}


And exposure period simultaneously with the increase in the recorded RNA and DNA concentrations. Expression of heat shock genes and transcription factors in the current study was determined by adopting the qPCR, results of which demonstrated an increase in gene activity with at the heat shock intensity increase, with increases of DNA, RNA concentrations. Nitrogenous bases sequences of thirty samples of callus of embryos, hypocotyl which exposed to heat shocks, and the comparison callus were determined by the specific polymerase chain reaction SPCR for detection of HSP90 genes. The purified DNA of chickpea plant was match with genes in the NCBI Genetic Data Bank, with many mutations whose effects varied in the amino acids type, thus, contributed to the identification of heat shock proteins. Phylogenetic tree data confirmed the existence of a close relationship between the chickpea cultivar under study and the Indian and Egyptian cultivars registered in NCBI by adopting molecular evidence represented by the genes of heat shock proteins.

Keywords: Chickpea (Cicer arietinum L.), Heat stress, Heat shock protein HSP90, RNA sequencing, gene Expression

\section{Introduction}

Chickpea (Cicer arietinum L.) is considered one of the most important types of food legumes in the world in economic terms, and cultivated at a rate of 14.56 million/hectares with a productivity of 11.68 million tons in more than 55 countries (1). The legume family (Fabaceae) constitutes the third largest family with more comprises than 650 genera and 18000 species, the genus Cicer includes 43 cultivated species (2). The annual chickpea plant is self-pollinating $2 \mathrm{n}=16$ (3).

Modern biological technologies have contributed to improving the production of leguminous crops and developing high-quality crop varieties. Legumes are among the crops sensitive to biotic and abiotic stresses (4). Plants deal with environmental stresses and cause a significant loss in production, because they pose a serious threat to plant survival. Despite this, plants have evolved a diverse set of adaptation mechanisms to resist environmental conditions through increased expression of heat shock genes (5). These genes activate metabolic pathways in plants to withstand the harmful effects of various stresses including temperature, drought, salinity, photooxidation, 
Heavy metals, high intensity radiation, wounds and other environmental factors (6). Most of the genes responsive to heat stress (HS) are involved in primary and secondary metabolic processes, translation, transcription, regulation and response to biological processes in plants such as calcium transport, phytohormones, sugars and lipids or protein synthesis including phosphorylation (7).

Heat shock proteins (HSPs) are considered essential in acquisition of heat tolerance in plants (8). The sources mentioned the positive effects of heat shock in a number of leguminous plant systems and its stimulation of metabolic pathways in cells represented in building new proteins, as in chickpea and soybean plants (9). Heat shock proteins (HSPs) function as molecular chaperones, successfully involved in the quality and type control of protein within living cells to maintain cellular homeostasis under environmental stress conditions (10). Heat shock of plant cells contributed to improving the plant species through changes in the fluidity of cell membranes and the accompanying changes at the molecular level. The expression of genes related to the regulation of the transcription process and synthesis of various proteins (11). Therefore, some plants respond to such stresses by reprogramming their proteins to ensure a steady state of metabolic processes that help them to survive and function under stress conditions (12). The genetic basis of chickpea is expected to be an important factor in stress tolerance by restoring cellular homeostasis and its direct effect on cellular and physiological changes (13).

Among the families of stress-responsive genes, there are HSP90. genes Known to be involved in both biotic and abiotic stresses and heat shock protein (HSP90) The family is important, because it not only regulates responses against various biotic and abiotic stresses in plants, but also play an important role in various developmental processes (14). Expression HSP9O against high temperatures is one of its best properties' responses. HSP9O escorts are basically, and expressed in most organisms under normal conditions, while, expression increases significantly under stress. HSP90s play a vital role in plant development, stress response and disease resistance (15). Recent studies have indicated that heat shock protein HSP9O is one of the most abundant proteins in living cells when exposed to abiotic stresses (16). This manuscript aimed to study the role of heat shock in chickpea callus growth, characteristics, and to identify heat shock genes HSP90 in exposed tissues to these shocks. 


\section{Materials and Methods}

\section{Embryos and Hypocotyl Production}

Cicer arietinum L. "Desi variety" seeds were sterilized by immersing in 96\% ethyl alcohol for $2 \mathrm{~min}$., submerging in sodium hypochlorate solution ( $\mathrm{NaOCl} 5 \%$ ) for $5 \mathrm{~min}$., then washed four times with sterile distilled water. Sterilized seeds were transferred to the surface of $25 \mathrm{ml}$ of solid basal MS medium free from growth regulators (17). in $100 \mathrm{ml}$ glass containers and incubated in culture room $23^{\circ} \mathrm{C}$, light intensity of 2000 lux at $8 / 16$ light / hour. Sterile seeds and seedlings were used as source of embryos and hypocotyls, respectively.

\section{Callus Initiation}

Sterilized seedlings 12-15 days old were excised, and divided into small pieces of $1.5 \mathrm{~cm}$ length. Embryos and hypocotyls fragment of each seedling were cultured on agar solidified MS medium containing $3 \%$ sucrose, provided with $1.0 \mathrm{mg} \mathrm{L}^{-1} \mathrm{NAA}$ and $2.0 \mathrm{mgl}-1 \mathrm{BA}(20)$ for callus initiation. The end cation was MS+NAA+BA cultures were kept at culture room conditions.

\section{Embryos and hypocotyls callus exposed to heat treatment}

A set of 30-day-old callus samples weighing $1 \mathrm{~g}$ were taken from hypocotyls and embryos and placed in sterile glass containers of $100 \mathrm{ml}$ and exposed to each temperature of 30, 35, 40, 45 and $50^{\circ} \mathrm{C}$. Exposure time 5, $10 \mathrm{~min}$. named short-term heat shock, and in the other treatment it appeared at the same temperature but for 15, 20 min., that called long term heat shock (18). Use a hot waterbath in the required degrees for both treatments. After exposure, all samples are placed directly in a baker of room temperature water to reduce their temperature. After exposing all samples were cultivated in MS medium mentioned previously.

\section{Assay HSP90 genes expression in exposed callus to heat shock}

The reverse transcription PCR was used to identify the cDNA strand by adopting mRNA as the genetic material isolated from callus to be the cDNA reverse amplification product. The basis for a second step was the quantitative amplification of the reverse amplification product by quantitative real time (qPCR) technique to assess the number of mRNA copies produced by expression of the target gene (Table 1). 


\section{Table 1: Sequence of primer set used in the study.}

\begin{tabular}{|c|c|c|c|}
\hline \multirow{2}{*}{ Gene } & Sequence 5'-3' & initiator & \multirow{2}{*}{ size (bp.) } \\
\hline \multirow{2}{*}{ HSP90 } & GCCTCCGTGCTTTGGTAA & Forward & \multirow{2}{*}{356 base pair } \\
\cline { 2 - 3 } & TGCCAAGAACCTCACCAGTA & Reverse & \\
\hline
\end{tabular}

\section{RNA isolation and RNA-seq}

The extracted RNA was reverse transcribed to cDNA using Prime Script 1st strand cDNA synthesis kit Miniprep RNA extract kit (S. Korea) Gene all. The cDNA was performed on Rotorgene Q real-time PCR system with SYBR Green PCR Kit (Wiz bioScript-TM cDNA synthesis Kit) and transcript specific primers. The cDNAs have been checked expression of heat stress marker (GMHsp90C2.1). This can validate for the plants applied heat stress (19). PCR primers were designed with the parameters of 17-25 nucleotide lengths, and 150-200 product size. PCR program was set as 5 minutes at $95^{\circ} \mathrm{C}, 40$ cycles each of 20 seconds at $95^{\circ} \mathrm{C}, 30$ seconds at $59^{\circ} \mathrm{C}$. Melt curve analysis was performed at the end of every PCRs. Threshold cycle for each reaction was normalized with expression value of Act B (B-actin). Relative expression values were calculated by 2-CT method (19). All experiments were processed with three biological replicates to obtained high credibility of experiments.

\section{Genetic determinants amplification and sequencing alignment}

sPCR Master Mix was $10 \mu \mathrm{l}$ (Gene All, S.Korea), additional components were $1 \mu \mathrm{l}(10 \mu \mathrm{M})$ of each of forward and reverse primer set (Ella Biotech ,Germany), $4 \mu$ l of gDNA (10ng\ml), the final volume was completed to $20 \mu \mathrm{l}$ with nuclease free water $(4 \mu 1)$. The ITS1, ITS 4 primer set that used in this research was listed in table one. Amplification steps were initial denaturation $95^{\circ} \mathrm{C}$ for $4 \mathrm{~min}$, then 35 cycles of each denaturation at $95^{\circ} \mathrm{C}$ for $30 \mathrm{sec}$., annealing temperature $60^{\circ} \mathrm{C}$ for 30 sec. to hybrid the primers, extension at $72^{\circ} \mathrm{C}$ for $30 \mathrm{sec}$., and final extension at $72^{\circ} \mathrm{C}$ for $5 \mathrm{~min}$. Amplification products were purified using PCR purification Kit (Gene All, S.Korea), which was sequenced using genetic lyzer (Applied Bio-systems3500. USA). The sequence was aligned (Mega $\mathrm{X}$-software) and assembled via National Center for Biotechnology Information (NCBI), using the Basic Local Alignment Search Tool (BLAST). 


\section{Phylogenetic Analysis}

Protein sequences of chickpea $H S P 90$ were aligned using phylogenetic tree was generated based on the MEGA software version 6.0. (Phoenix, AZ, USA) (20). and protein formation of Cicer arietinum heat shock $90 \mathrm{kDa}$ protein gene using Expasy software (21).

\section{Result}

Detection of heat shock protein $\mathrm{HSP90}$ gene expression activity in embryogenic and hypocotyls callus exposed to heat shock.

Gene expression of $H S P 90$ (heat shock protein) samples were determined by RT-PCR techniques. These techniques revealed the activity of the HSP90 genes of the standard gene Beta Actin in the early stages of the amplification processes during the reaction (Fig.1).

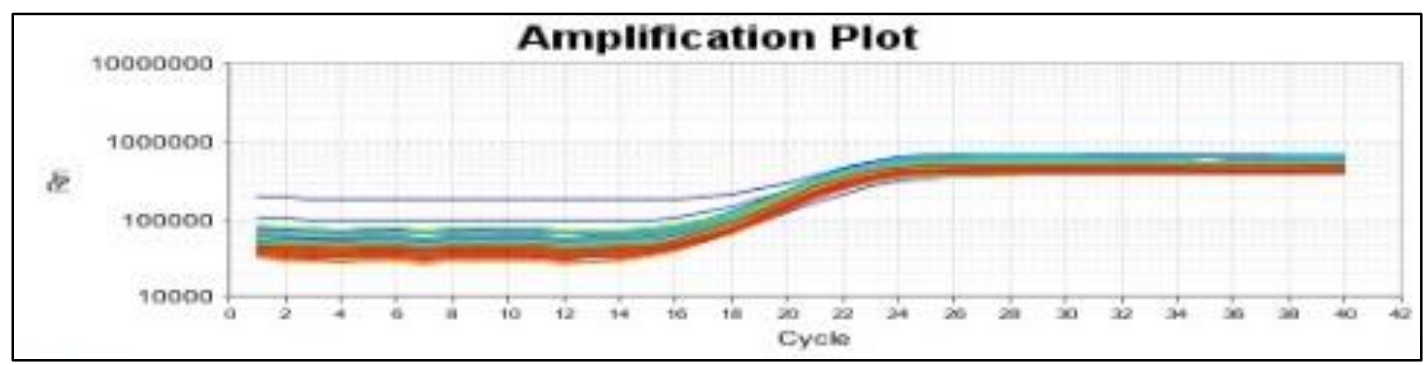

Fig.1: Expression of the $\beta$ Actin gene standard for heat shock proteins $H S P 90$ of chickpea Cicer arietinum $\mathbf{L}$.

Each of embryonic and hypocotyls callus exposed to heat shock and control samples was determined by adopting the reading of a Nano Spectrometer (nano, 2000, Thailand) at wavelength of 260 / $280 \mathrm{~nm}$. Nuclear RNA in the callus exposed to heat shock $45^{\circ} \mathrm{C} / 15$ and $20 \mathrm{~min}$., additionally to non-exposed callus (Table 2).

Table 2: Concentration and purity of RNA isolated from tissues of embryonic callus and hypocotyls callus of chickpea Cicer arietinum $\mathbf{L}$. exposed and not exposed to heat shock.

\begin{tabular}{|c|c|c|c|c|}
\hline \multicolumn{3}{|c|}{ Embryonic calli } & \multicolumn{2}{c|}{ Hypocotyls calli } \\
\hline Samples & Purity & RNA (ng/ $\mu)$ & Purity & RNA (ng/ $\mu)$ \\
${ }^{\circ} \mathrm{C} /$ min & $280 / 260$ & Hypocotyls & $280 / 260$ & Embryo callus \\
\hline
\end{tabular}


Academic Journal of Research and Scientific Publishing | Vol 3 | Issue 33

Publication Date: 5-1-2022

ISSN: 2706-6495

\begin{tabular}{|c|c|c|c|c|}
\hline control & 1.9 & 6012 & 1.9 & 8149 \\
\hline 30 & 1.7 & 6582 & 1.7 & 6635 \\
\hline 35 & 1.9 & 7313 & 2 & 7283 \\
\hline 40 & 1.8 & 9377 & 1.8 & 12462 \\
\hline 45 & 1.7 & 9628 & 1.9 & 16539 \\
\hline 50 & 1.8 & 11901 & 1.8 & 6175 \\
\hline
\end{tabular}

Detection of $H S P 90$ gene expression activity in embryonic and hypocotyls callus exposed to heat shock.

Samples of RNA samples extracted from the genetic repertoire were amplified for the purpose of stabilizing the genetic expression of HSP90 genes in RNA samples extracted from embryonic callus and hypocotyls callus under study. High temperatures degree stimulated the activity of HSP90 gene expression and the melting curve of HSP90 heat shock protein genes, which shows the absence of dimer in the callus samples under study (Fig.2).

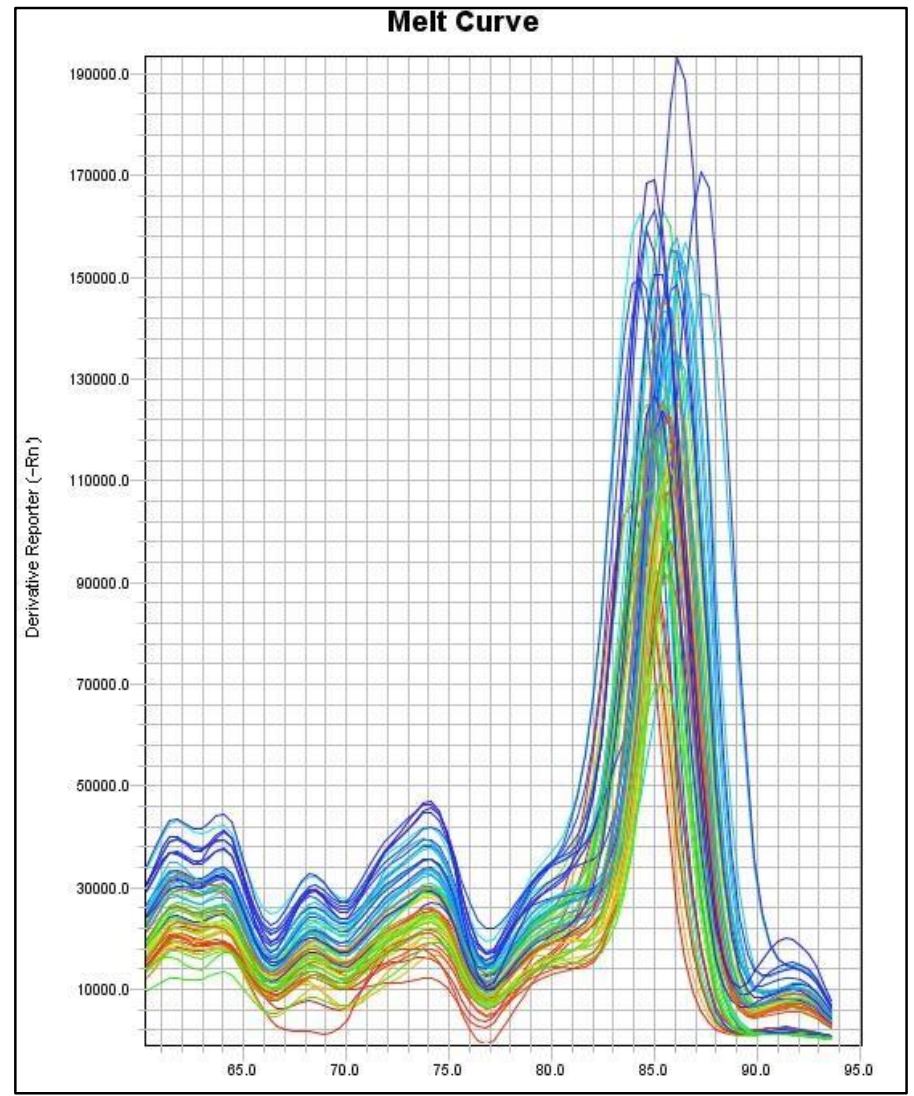




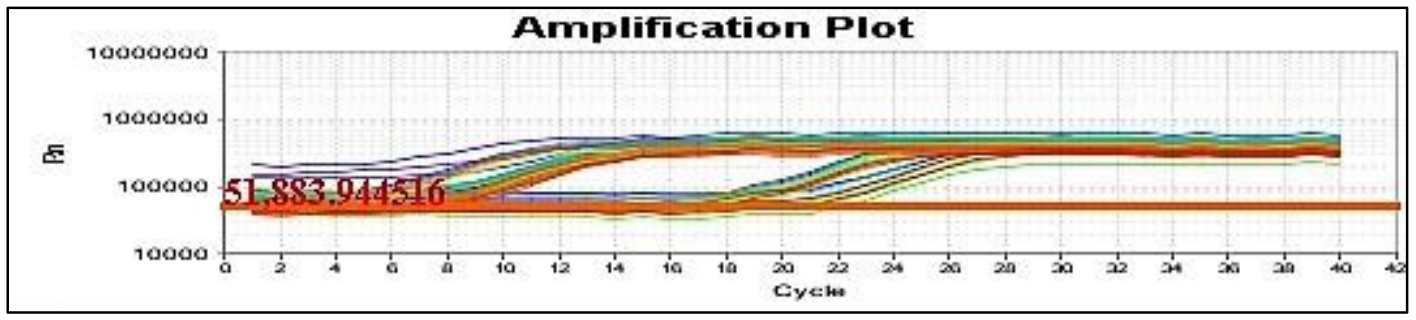

Fig. 2: Melting curve and genetic expression of heat shock protein $H S P 90$ genes of embryonic and hypocotyls calli of Cicer arietinum L. exposed to heat shock.

The achieved results (Table 3) demonstrated a high increase in the activity of the HSP9O gene responsible for shock proteins in terms of increase in expression levels of the $\Delta \mathrm{ct}$ gene when callus exposed to heat shock with a selected duration 5-20 min. For the shock of the embryonic callus exposed to $45^{\circ} \mathrm{C}$ and $50^{\circ} \mathrm{C}$, compared to samples exposed to low temperatures and after thirty days of exposure to both STHS and LTHS which recorded a slight increase in activity of HSP9O gene. Long-term heat shock achieved an increase in the amount of RNA, as it was noted that its purity was suitable for performing simultaneous sequence replication qPCR.

Table 3: HSP90 gene expression activity of embryonic callus of chickpea Cicer arietinum L. exposed to heat shock

\begin{tabular}{|c|c|c|c|}
\hline $\begin{array}{c}\text { Embryonic callus } \\
\text { C / min }\end{array}$ & Beta actin & HSP90 & $\Delta$ ct \\
\hline control & 18.83878 & 23.09563 & 0 \\
\hline $30 / 10$ & 19.12056 & 20.55118 & $\begin{array}{c}- \\
2.826241493\end{array}$ \\
\hline $35 / 5$ & 19.41429 & 10.53783 & $\begin{array}{c}- \\
13.13332415\end{array}$ \\
\hline $40 / 20$ & 19.31317 & 9.936205 & -13.6338253 \\
\hline $45 / 15$ & 18.9709 & 9.407584 & $\begin{array}{c}- \\
13.82017231\end{array}$ \\
\hline $50 / 15$ & 19.29653 & 7.027575 & $\begin{array}{c}- \\
13.82017231\end{array}$ \\
\hline
\end{tabular}

Whereas, data of qPCR products indicated that heat shock supported high levels of $\Delta \mathrm{ct}$ and stimulated the HSP90 gene for hypocotyls callus. 
It was noted that the activity of the gene stimulating heat shock proteins increase at its highest levels, and the amount of RNA increased with highe temperatures and exposure time compared to the rest of treatments and controls (Fig.3).

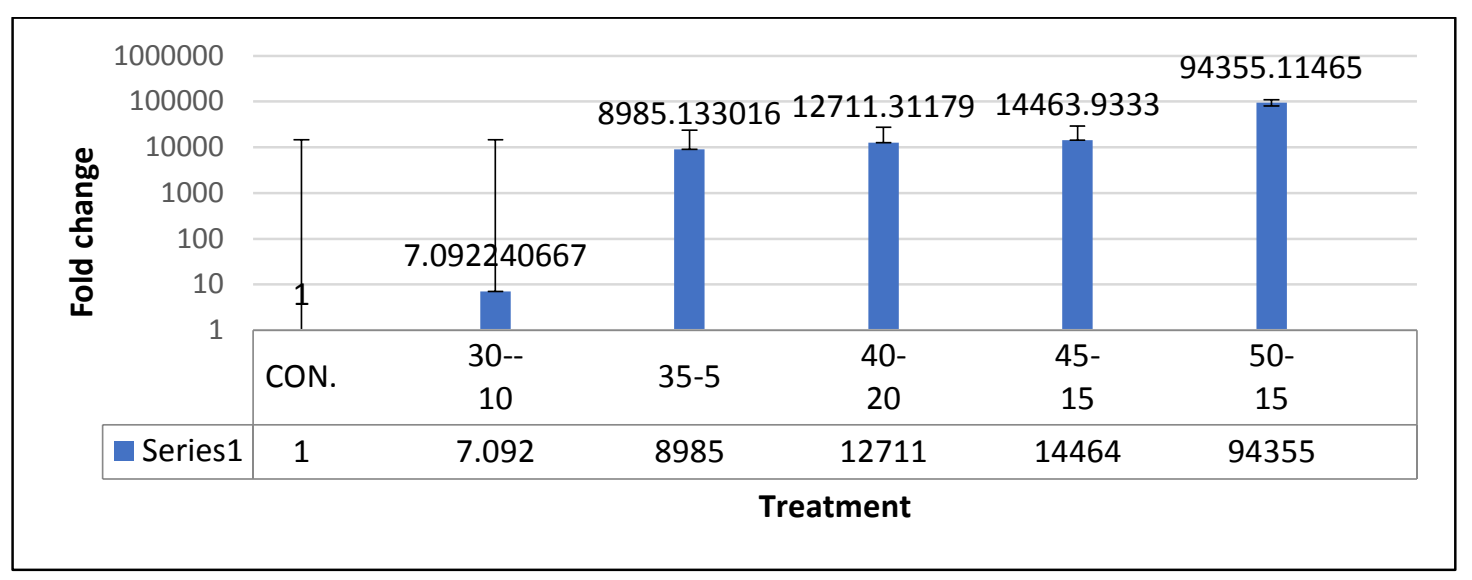

Fig. 3: Histogram of HSP90 gene expression activity of the embryonic callus of chickpea Cicer arietinum L. exposed to heat shock.

Data of qPCR products (Table 4) indicated that heat shock supported high levels of $\Delta \mathrm{ct}$ and stimulated HSP90 gene of hypocotyls callus (Fig.4). It was noted that the activity of the gene stimulating heat shock proteins increased at its highest levels, and the amount of RNA increased with higher temperatures and exposure time compared to the remaining of the treatments and comparisons.

Fig. 4: Histogram of the HSP90 gene expression activity of the hypocotyl's callus of chickpea Cicer arietinum $\mathrm{L}$. exposed to heat shock.

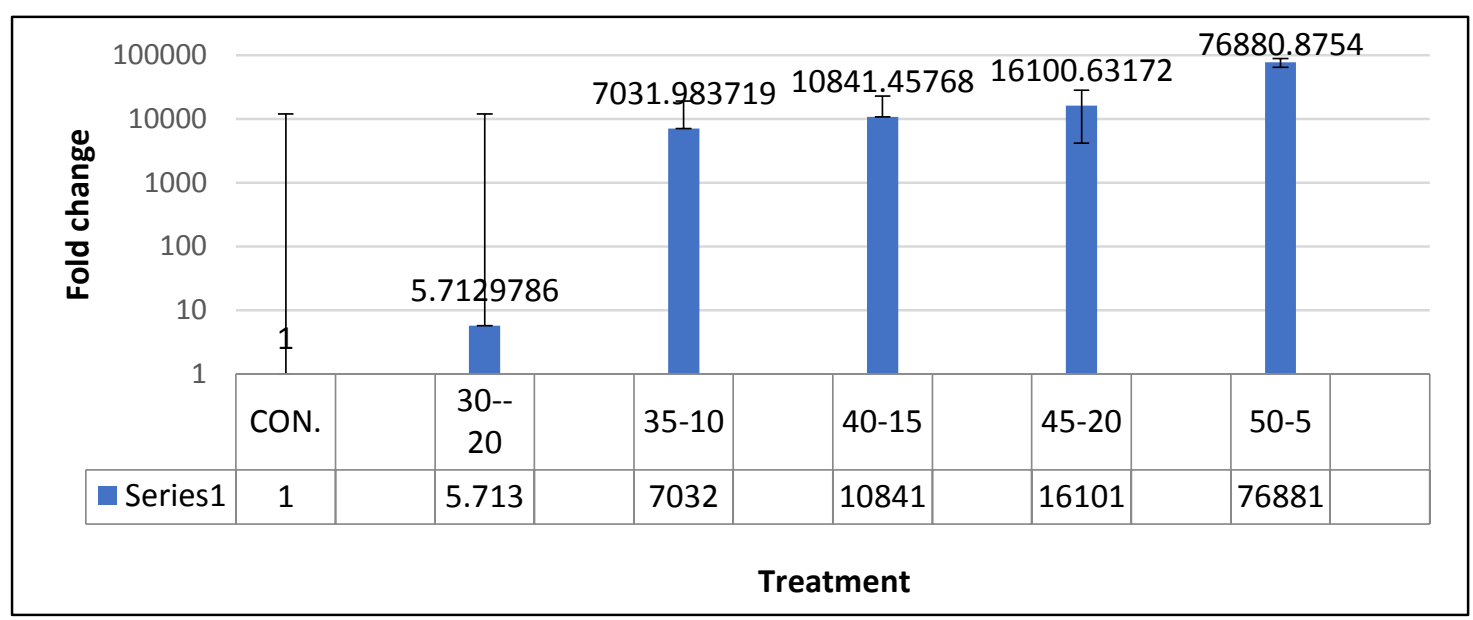




\begin{tabular}{|c|c|c|c|}
\hline $\begin{array}{c}\text { hypocotyls callus } \\
\mathrm{C} / \mathrm{min}^{\circ}\end{array}$ & Beta actin & HSP90 & $\Delta \mathrm{ct}$ \\
\hline control & 18.83878 & 23.09563 & 0 \\
\hline $30 / 20$ & 19.03487 & 20.77749 & -2.514243126 \\
\hline $35 / 10$ & 18.83764 & 10.31478 & -12.77971601 \\
\hline $40 / 15$ & 19.05466 & 9.907241 & -13.40427113 \\
\hline $45 / 20$ & 19.32304 & 9.605064 & -13.97482967 \\
\hline $50 / 5$ & 19.12325 & 7.149771 & -16.23033714 \\
\hline
\end{tabular}

Table 4: HSP90 gene expression activity of the hypocotyl callus of chickpea Cicer arietinum $\mathrm{L}$. subjected to heat shock.

Molecular investigation of the genes of heat shock proteins HSP90 in embryogenic and hypocotyls calli of chickpea Cicer arietinum $\mathrm{L}$.

\section{Isolation of genomic DNA}

The concentration of deoxygenated DNA extracted from samples of embryogenic and hypocotyls calli subjected to physical shock and control samples were determined by adopting the reading of a nano spectrophotometer (Nano 2000, Thailand) at wavelength of 260/280 nm and DNA concentration in callus was superior. subjected to heat shock $40^{\circ} \mathrm{C} / 20 \mathrm{~min}$.

\section{Nitrogenous base sequences for PCR products}

Sequencing technology aimed to determine the relative positions of nitrogenous bases of DNA pieces obtained from the specialized replication reaction of DNA samples extracted from callus samples demonstrate to confirm the diagnosis of chickpea callus by adopting sequence alignment of the nitrogenous bases of the HSP90 genes.

\section{Molecular expiantion of the HSP90 gene.}

The results of PCR indicate performed for DNA samples isolated the extracted DNA products were obtained from samples of one size (356) base pair (Fig.5) and it has the ability to encode 237 amino acids in chickpea plant. 


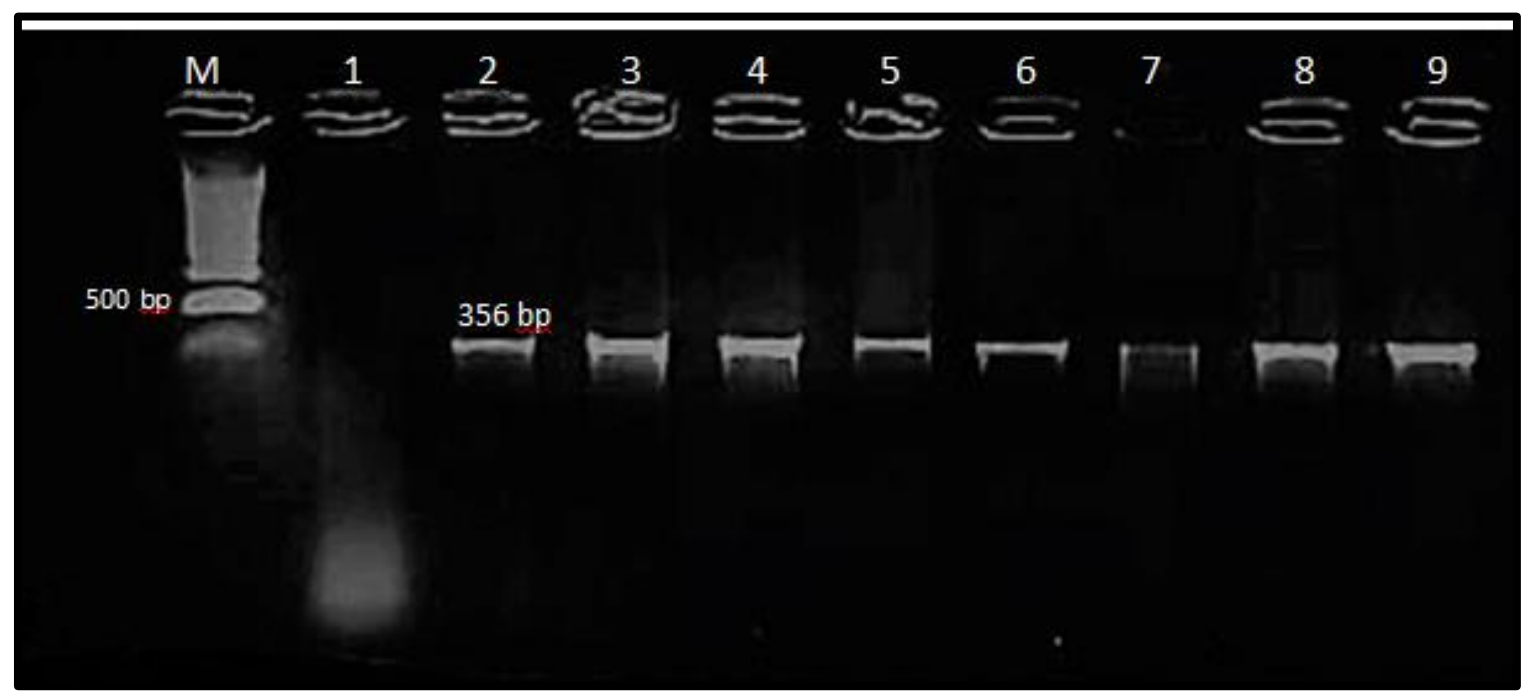

Fig. 5: Bundle of DNA bands of Cicer arietinum L. amplified for the HSP90 gene.

- Lane (M) represents the molecular scale

- Lane (1) represents the control

- Lane (2 - 9) represents a positive result for the presence of the bands representing the gene HSP90 (356) base pair of the embryo and hypocotyls callus of chickpea.

The results showed the alignment of the nitrogenous bases of 356 nitrogenous bases of chickpea calli samples with their complementary nitrogenous bases of HSP90 gene, as follows:

The sequences of embryogenic callus samples subjected to heat shock were entered into the NCBIBLAST program available at https://blast.ncbi.nlm.nih.gov/Blast.cgi and the MEGA6.0+ BLAST program to analyze these sequences and show their affinity with the existing sequences. Results of analysis showed a significant similarity of $-99 \%$ between these sequences and the sequences recorded in the Gene Bank with the number XM_004491473.2. (Table 5) shows a comparison of the DNA sequences of the samples of the embryonic callus, as it was noted that there are areas of replacement there were mutations of the type of transition at the site (573) that did not affect the genetic code and then the type of amino acid that constitutes the shock protein HSP9O.

Table 5: Analysis of the DNA sequences of $H S P 90$ genes from chickpea Cicer arietinum L. embryonic callus exposed to heat shock. 
Academic Journal of Research and Scientific Publishing | Vol 3 | Issue 33

Publication Date: 5-1-2022

ISSN: 2706-6495

\begin{tabular}{|c|c|c|c|c|c|c|c|c|}
\hline \multicolumn{9}{|c|}{ Source: Cicer arietinum heat shock 90 kDa protein } \\
\hline $\begin{array}{c}\text { Sampl } \\
\text { e } \\
{ }^{\circ} \mathrm{C} / \\
\min \end{array}$ & $\begin{array}{l}\text { Type of } \\
\text { substitut } \\
\text { ion }\end{array}$ & $\begin{array}{l}\text { Locati } \\
\text { on }\end{array}$ & $\begin{array}{l}\text { Nucleot } \\
\text { ide }\end{array}$ & $\begin{array}{l}\text { Nucleot } \\
\text { ide } \\
\text { change }\end{array}$ & $\begin{array}{c}\text { Amin } \\
\text { o acid } \\
\text { chang } \\
\text { e }\end{array}$ & $\begin{array}{c}\text { Predict } \\
\text { ed } \\
\text { effect }\end{array}$ & $\begin{array}{l}\text { Sequence ID } \\
\text { with compare }\end{array}$ & $\begin{array}{c}\text { Identiti } \\
\text { es }\end{array}$ \\
\hline $\begin{array}{c}\text { Contr } \\
\text { ol }\end{array}$ & $\begin{array}{c}\text { Transitio } \\
\mathrm{n}\end{array}$ & 573 & $\mathrm{G} \backslash \mathrm{A}$ & $\begin{array}{c}\text { GAG } \backslash \mathrm{G} \\
\mathrm{AA}\end{array}$ & $\begin{array}{l}\text { Gluta } \\
\text { mic } \\
\text { acid } \backslash \\
\text { Gluta } \\
\text { mic } \\
\text { acid }\end{array}$ & Silent & ID: $\frac{\text { XM_004491 }}{\underline{473.2}}$ & $99 \%$ \\
\hline $\begin{array}{c}/ 10 \\
30\end{array}$ & $\begin{array}{c}\text { Transitio } \\
\mathrm{n}\end{array}$ & 573 & $\mathrm{G} \backslash \mathrm{A}$ & $\begin{array}{c}\text { GAG\G } \\
\text { AA }\end{array}$ & $\begin{array}{c}\text { Gluta } \\
\text { mic } \\
\text { acid } \\
\text { Gluta } \\
\text { mic } \\
\text { acid }\end{array}$ & Silent & ID: $\frac{\text { XM_004491 }}{\underline{473.2}}$ & $99 \%$ \\
\hline $35 / 5$ & $\begin{array}{c}\text { Transitio } \\
\mathrm{n}\end{array}$ & 573 & $\mathrm{G} \backslash \mathrm{A}$ & $\begin{array}{c}\text { GAG } \backslash \mathrm{G} \\
\mathrm{AA}\end{array}$ & $\begin{array}{c}\text { Gluta } \\
\text { mic } \\
\text { acid } \backslash \\
\text { Gluta } \\
\text { mic } \\
\text { acid }\end{array}$ & Silent & ID: $\frac{\text { XM_004491 }}{\underline{473.2}}$ & $99 \%$ \\
\hline $\begin{array}{c}/ 20 \\
40\end{array}$ & $\begin{array}{c}\text { Transitio } \\
\mathrm{n}\end{array}$ & 402 & $\mathrm{G} \backslash \mathrm{A}$ & $\begin{array}{c}\text { TTG } \ \text { AT } \\
\text { A }\end{array}$ & $\begin{array}{l}\text { Leucin } \\
\text { el } \\
\text { Leucin } \\
\text { e }\end{array}$ & Silent & ID: $\frac{\text { XM_004491 }}{\underline{473.2}}$ & $99 \%$ \\
\hline $\begin{array}{l}/ 15 \\
45\end{array}$ & $\begin{array}{c}\text { Transitio } \\
\mathrm{n}\end{array}$ & 573 & G\A & $\begin{array}{c}\text { GAG } \backslash \mathrm{G} \\
\mathrm{AA}\end{array}$ & $\begin{array}{l}\text { Gluta } \\
\text { mic } \\
\text { acid } \backslash \\
\text { Gluta } \\
\text { mic } \\
\text { acid }\end{array}$ & Silent & & \\
\hline $\begin{array}{c}/ 15 \\
50\end{array}$ & $\begin{array}{c}\text { Transitio } \\
\mathrm{n}\end{array}$ & 573 & $\mathrm{G} \backslash \mathrm{A}$ & $\begin{array}{c}\text { GAG } \backslash \text { G } \\
\text { AA }\end{array}$ & $\begin{array}{l}\text { Gluta } \\
\text { mic } \\
\text { acid } \backslash \\
\text { Gluta } \\
\text { mic } \\
\text { acid }\end{array}$ & Silent & ID: $\frac{\text { XM_004491 }}{\underline{473.2}}$ & $99 \%$ \\
\hline
\end{tabular}


Analysis results (Table 6) of nitrogenous bases sequences of the heat shocked hypocotyls callus samples subjected to heat shock and their convergence with the existing sequences recorded in the gene bank. The areas of substitution between the nitrogenous bases were observed between callus sample subjected to heat shock $35^{\circ} \mathrm{C} / 10 \mathrm{~min}$ and registered in NCBI. It was a substitution site 398 and the mutation affected the genetic codes and then the encoded amino acids, as amino acid threonine was replaced by lysine. While the mutations in the callus samples exposed to heat shock did not affect the type of amino acids encoded.

Table 6: Analysis of the DNA sequences of $H S P 90$ genes from chickpea Cicer arietinum L. hypocotyls callus exposed to heat shock.

\begin{tabular}{|c|c|c|c|c|c|c|c|c|}
\hline \multicolumn{9}{|c|}{ Source: Cicer arietinum heat shock 90 kDa protein } \\
\hline $\begin{array}{c}\text { Sampl } \\
\mathbf{e} \\
\mathrm{C} /{ }^{\circ} \\
\min \end{array}$ & $\begin{array}{c}\text { Type of } \\
\text { substitutio } \\
n\end{array}$ & $\begin{array}{c}\text { Locatio } \\
\mathbf{n}\end{array}$ & $\begin{array}{l}\text { Nucleoti } \\
\text { de }\end{array}$ & $\begin{array}{l}\text { Nucleotid } \\
\text { e change }\end{array}$ & $\begin{array}{l}\text { Amino } \\
\text { acid } \\
\text { change }\end{array}$ & $\begin{array}{r}\text { Predicte } \\
\text { d effect }\end{array}$ & $\begin{array}{l}\text { Sequence ID with } \\
\text { compare }\end{array}$ & $\begin{array}{c}\text { Identiti } \\
\text { es }\end{array}$ \\
\hline $\begin{array}{c}\text { Contro } \\
1\end{array}$ & Transition & 573 & $\mathrm{G} \backslash \mathrm{A}$ & $\begin{array}{c}\text { GAG\GA } \\
\text { A }\end{array}$ & $\begin{array}{c}\text { Glutamic } \\
\text { acid } \backslash \\
\text { Glutamic } \\
\text { acid }\end{array}$ & Silent & ID: $\frac{\text { XM_00449147 }}{\underline{3.2}}$ & $99 \%$ \\
\hline $30 / 20$ & Transition & 573 & G\A & $\begin{array}{c}\text { GAG\GA } \\
\text { A }\end{array}$ & $\begin{array}{c}\text { Glutamic } \\
\text { acid } \backslash \\
\text { Glutamic } \\
\text { acid }\end{array}$ & Silent & ID: $\frac{X M \_00449147}{\underline{3.2}}$ & $99 \%$ \\
\hline $35 / 10$ & $\begin{array}{c}\text { Transverti } \\
\text { on } \\
\end{array}$ & 398 & $\mathrm{C} \backslash \mathrm{A}$ & $\begin{array}{c}\text { ACA } \backslash A A \\
\text { A } \\
\end{array}$ & $\begin{array}{l}\text { Threonin } \\
\text { el Lysine }\end{array}$ & $\begin{array}{c}\text { Missens } \\
\mathrm{e} \\
\end{array}$ & ID: $\frac{\text { XM_00449147 }}{\underline{3.2}}$ & $99 \%$ \\
\hline $40 / 10$ & Transition & 573 & G\A & $\begin{array}{c}\text { GAG\GA } \\
\text { A }\end{array}$ & $\begin{array}{c}\text { Glutamic } \\
\text { acid } \backslash \\
\text { Glutamic } \\
\text { acid }\end{array}$ & Silent & & \\
\hline $40 / 15$ & Transition & 573 & G\A & $\begin{array}{c}\text { GAG\GA } \\
\text { A }\end{array}$ & $\begin{array}{c}\text { Glutamic } \\
\text { acid } \backslash \\
\text { Glutamic } \\
\text { acid }\end{array}$ & Silent & ID: $\frac{X M \_00449147}{\underline{3.2}}$ & $99 \%$ \\
\hline $45 / 20$ & Transition & 573 & G\A & $\begin{array}{c}\text { GAG\GA } \\
\text { A }\end{array}$ & $\begin{array}{c}\text { Glutamic } \\
\text { acid } \backslash \\
\text { Glutamic } \\
\text { acid }\end{array}$ & Silent & ID: $\frac{X M 00449147}{\underline{3.2}}$ & $99 \%$ \\
\hline
\end{tabular}


Academic Journal of Research and Scientific Publishing | Vol 3 | Issue 33

Publication Date: 5-1-2022

ISSN: 2706-6495

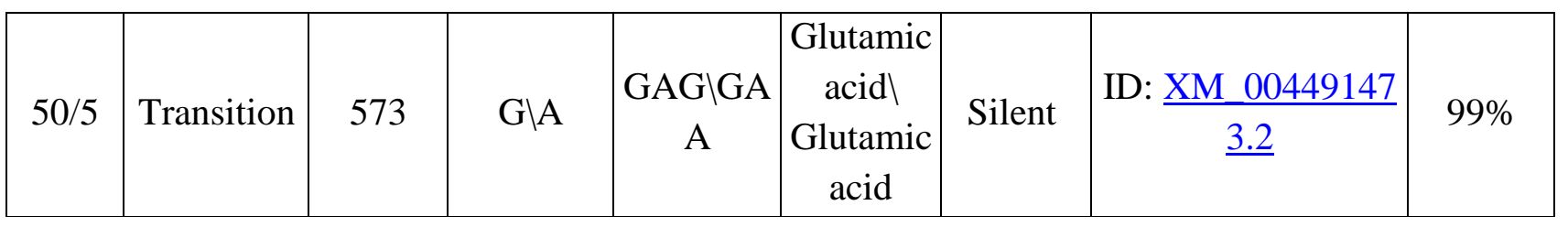

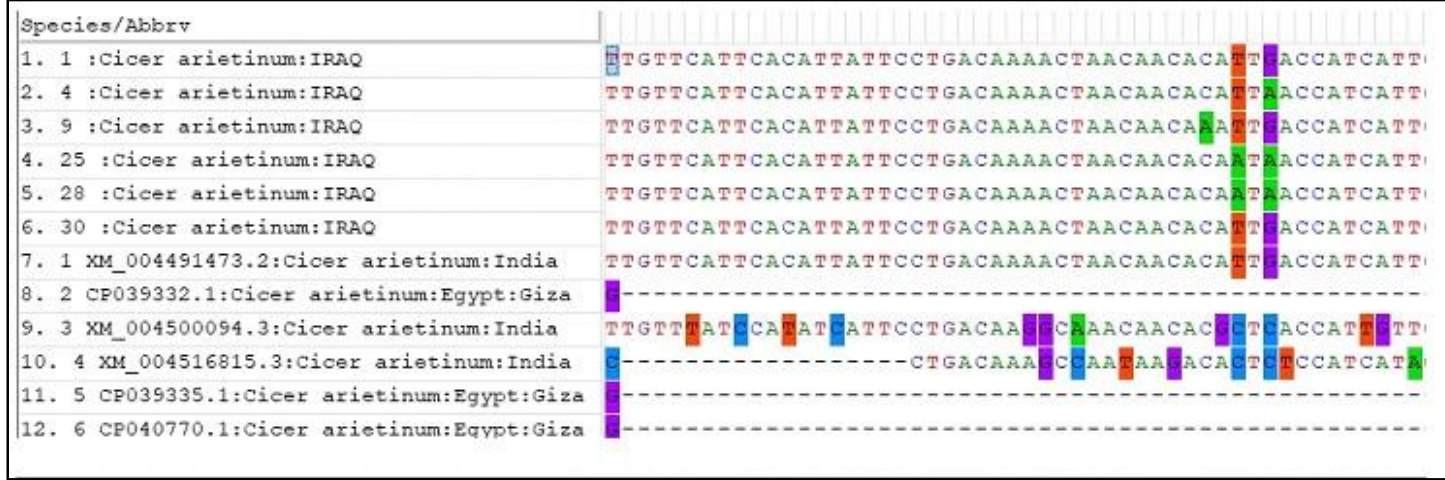

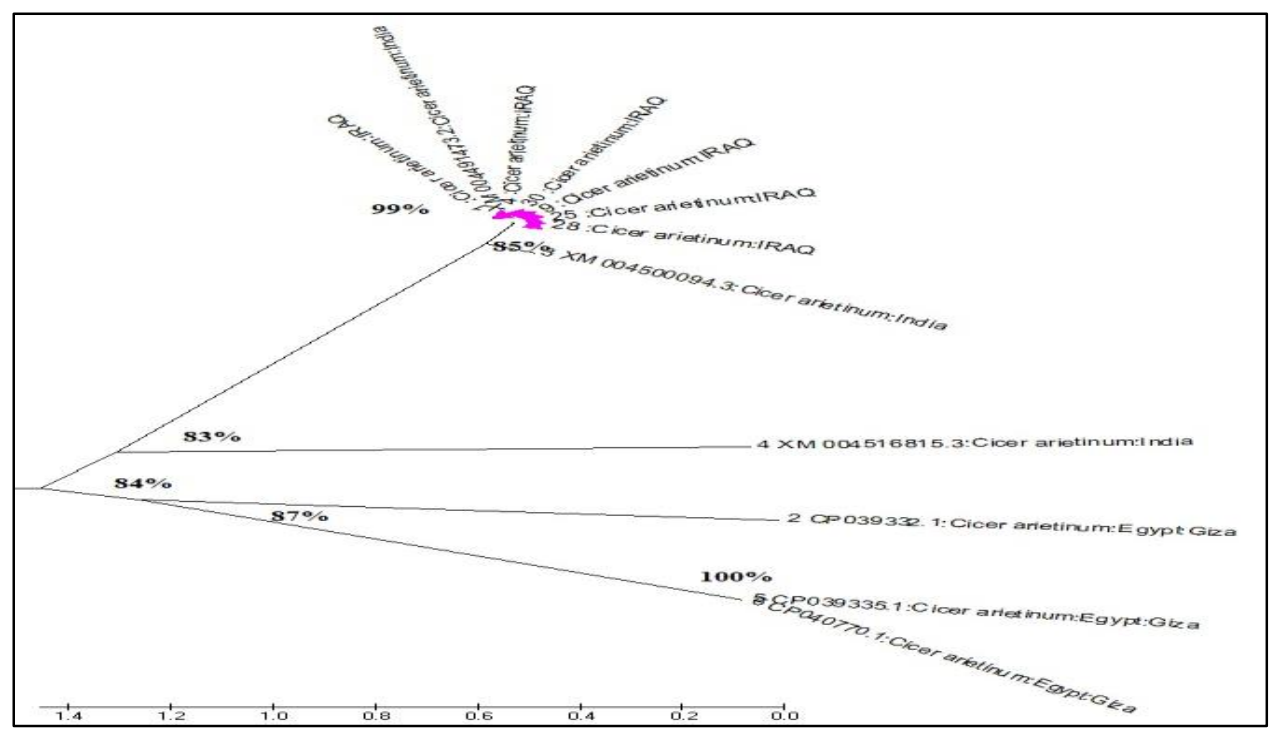

Fig. 6: Neighbor-joining tree Cicer arietinum heat shock 90 kDa protein gene.

It was noted from the genotype tree diagram that the standard cultivars registered in NCBI were from countries far from Iraq and the region in general. This indicates that the current study was one of the first studies at the local level that concerned itself with the genetic characterization of chickpea calluses based on the genes of heat shock proteins HSP90, as compared with international varieties, the presence of any genetically diagnosed local chickpea cultivar was not recorded in the gene bank. This results of the current study were able to reveal HSP90 genes from the chickpea genetic tree based on genome sequence information available in the NCBI Gene Bank which has the potential to genetically improve tolerance to abiotic stresses. 
The heat shock protein HSP90 was drawn by inserting an alignment sequence of the nitrogen base sequences of the genes of heat shock proteins HSP90 for selected samples of chickpea callus and based on the mutations induced in the Expasy program as shown in the figure below.
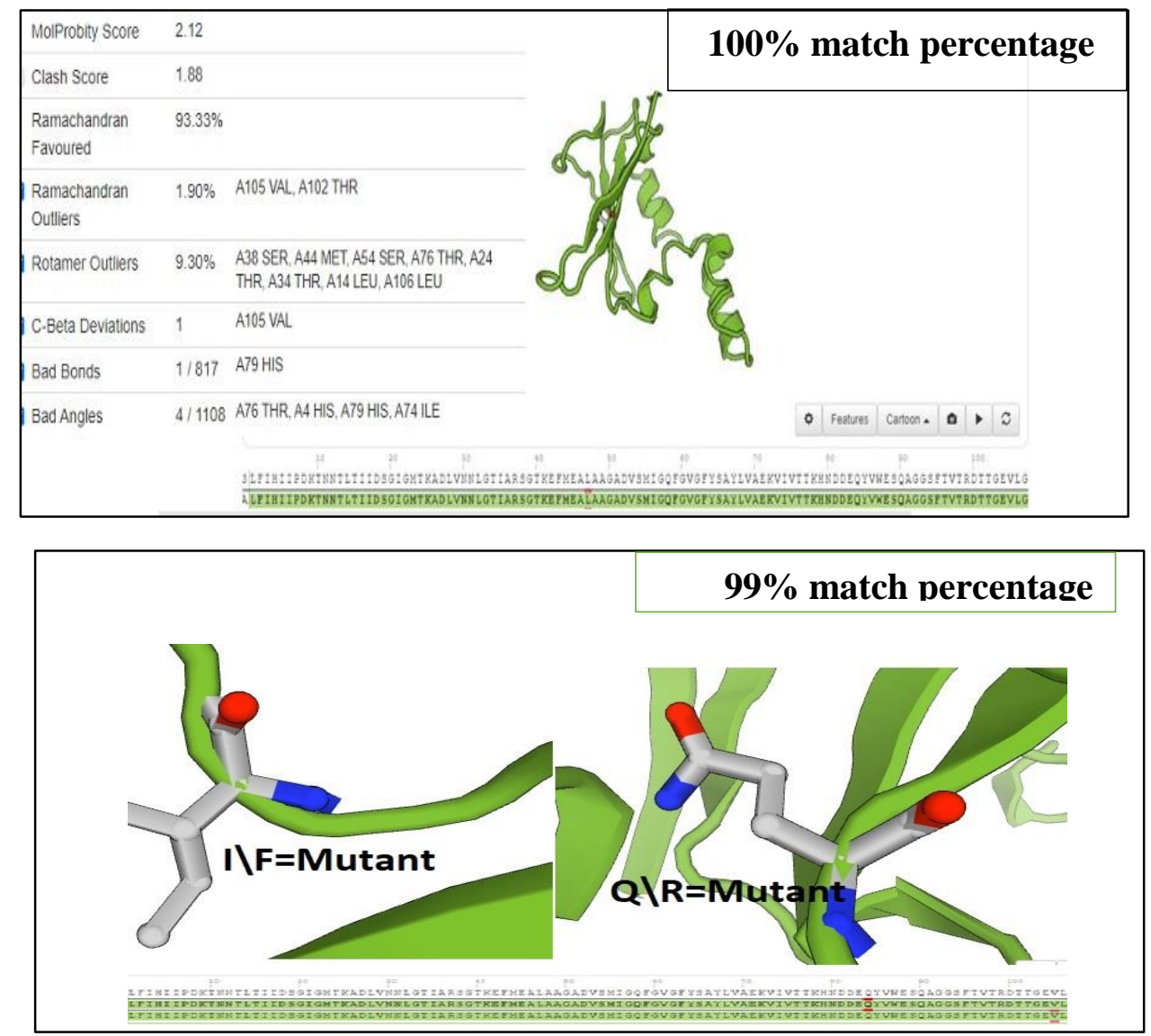

Fig. 7: Conformation of protein from chickpea Cicer arietinum L. heat shock 90 kDa protein gene

\section{Discussion}

The success of the current study in finding an integrated protocol for obtaining chickpea plants by means of plant tissue culture technique is due to the ex vivo response of chickpea plants combined with the appropriateness of the selected hormonal interventions. Moreover, the need to genetically improve chickpea by obtaining cell lines resistant to environmental stresses (22). Physical shock provokes multiple responses that include a series of chemical and molecular changes, 
And that multiple stress-responsive mechanisms work in concert and synergistically to avoid cellular damage (23). This is due to the increase in the construction of heat shock proteins HSP90, as cells respond to stress to increase their genetic expressions that encode for the construction of these proteins this is due to their stimulation of heat shock factors HSFs, which play an important role in activating the $H S P 90$ gene group. The construction of shock proteins HSP90 was also stimulated when tissue cultures of soybean and Arabidopsis were exposed to a degree 40 centigrade (15). The heat shock in the current study resulted in an increase in the accumulation of specific shock proteins HSPs, and synthesis synthesis of a group of proteins is an important event to adapt to heat stress. This is due to the increase and abundance of a specific number of enzymes that stimulate the synthesis of amino acids such as 5-methyl tetrahydroptroyltri glutamate- homo cysteine methyl transferase- Cystathionine gamma- Synthase., thereonine synthase (8). Among the indicators that explain the construction of heat shock proteins HSPs is that they stimulated the activity of genetic expression and encode its construction by activating a group of genes of shock proteins $H S P 90$, especially at temperatures of $45^{\circ} \mathrm{C}$ or less, as they provided protection for the callus from damage and restored its damaged cells to their physiological activity, and preserved the structure of damage-induced proteins (24).

In this study obtaining callus tissues that are resistant to abiotic shocks is represented by the activity of genes of heat shock proteins HSP90 in mitochondria of callus tissues, which have a vital role in heat tolerance through the mutations formed and activating the transcription of target genes $H S F$ s. This affect the stress tolerance mechanism as they are considered a regulator. Key to signal perception, transmission and control of expression of effector genes (25).

Confirmation the diagnosis of HSP90 genes in callus of chickpea Cicer arietinum L. It proved the presence of heterogeneity at the nitrogen base level at site 250 represented by mutations R and G. A study (26) showed thmentionede discovery of induced mutations of the genes of heat shock proteins HSP90 in rice, which showed a characteristic tolerance to HS stress. The shock proteins are able to tolerate a large numbers of mutations without undergoing significant changes in function.

The exploration of genes of heat shock proteins HSP90 through molecular analysis of the genetic relationship between species of the genus Chickpea has a great affinity of up to $99 \%$, 
while it was found that there is a level of convergence of $83 \%$ among the other chickpea species under study, which indicates bio genetic diversity and that the standard chickpea cultivars The records in the National Center for Biotechnology Information (NCBI) were from countries far from Iraq and the region in general.

\section{Acknowledgment}

Thanks are due to the Department of Biology, College of Education for Pure Science, university of Mosul. Also, to all colleges in biotechnology lab.

\section{References}

[1] Food and agriculture organization of the United Nations (2019). World Food and AgricultureStatistica pocketboo. http://www.fao.org/3/ca6463en/ca6463en.pdf.

[2] Dixit, G. P.; A. K. Srivastava and Singh N.P. (2019). Marding towards self - sufficiency in chickpea. Current Science, 116:239-242.

[3] Singh, R.K.; J. Jashankar; M. Muthamilarasan; S. Shweta; A. Dangi and Preasad, M. (2016). Genome - wide analysis of heat shock proteins in $\mathrm{C} 4$ model, foxtail millet identifies potential candidates for crop improvement under abiotic stress. Scientific Reports, 6: 32641.

[4] Singh, K.B. and Saxena, M.C. (1999). Chickpea (The Tropical Agriculturalist). CTA/ Macmillan/ ICRDA. 34 PP. Macmillam Education Ltd. London, UK.

[5] Raza, A.; A. Razzaq; S. Mehmood; X. Zou; X. Zhang; Y. Lv and Xu J. (2019). Impact of Climate Change on Crops Adaptation and Strategies to Tackle Its Outcome: A Review. Plants. 8: 34.

[6] Govindaraj, M.; S. K. P. Shetti; N. Patne and Kanatti, A. A. (2018). Breeding cultivars for heat stress tolerance in staple food crops. In: Ciffci YO, ed. Next generation plant breeding. In Tech Open.

[7] Takahashi, F. and Shinozaki K. (2019). Long - distance signaling in plant stress response. Current Opirion in Plant Biology, 47: 106-111.

[8] Mirshra, D.; S. Shekhar; D. Singh and Chakraborty S. (2018). Regulation of Heat shock protein Responses, Heat Shock protein. National Institute of plant Genome Research. Chapter 3: 41-69. 
[9] Sotirisos, F.; R. Sascha; S. Enrico and Klaus D. S. (2015). Prospects of engineering thermo tolerance in crops through modulation of heat stress transcription factor and heat shock protein networks. Plant cell \& Environment, 38: 1881-1895.

[10] Waters, E. R. (2013). The Evolution function, Structure, and expression of the plant HSPs. Journal of Experimental Botany, 64:391-403.

[11]Berz, J.; S. Simm; S. Schuster; K. D. Scharf; E. Schleiff and I. Ebersberger (2019). Heat stress: a databases and web server for identification and classification of heat stress transcription factors in plants. Bioinformatic and Biology insights, 13.

[12] Rani, A.; P. Devi; U. Jha; K. Sharma; K. Siddique and Bayyar H. (2020). Developing climate resilient chickpea involving physiological and molecular approaches with a focus on temperature and drought stresses. Frontiers in Plant Science, 10: 1759.

[13] Santisree, P.; M. P. Bhatnagar and Sharma K. (2017). Heat responsive proteome changes reveal molecular mechanism un delaying heat tolerance in chickpea. Environmental and Experimental Botany, 141: 132-144.

[14]Michela, J.; Mariolina, G.; M. Elena; M. Marta; V. Babu; T. N. Henry and Nelson M. (2020). Molecular and genetic basses of heat stress responses in crop plants and breeding for incurs seed resilience and productivity. Journal of Experimental Botany, 71: 3780-3802.

[15] Xu, J.; C. Xue; D. Xue; J. Zhao; J. Gai; N. Guo and Xing H. (2013). Overexpression of GmHsp90s, a heats shock protein 90 (HSP90) gene family cloning from soybean, decrease damage of abiotic stresses in Arabidopsis thaliana. PLoS One, 8(7).

[16] Agrwal, G.; V. Garg; H. Kudapo; D. Doddamani and Pazhamala L. T. (2016). Genome - wide dissection of AP2/ ERF and HSP90 gene families in five legumes and expression profile in chickpea and pigeon pea. Plant Biotech. J., 10: 1-15.

[17]Murashige, T. and Skoog F. (1962). Arevised medium for rapid growth and bioassays with tobacco tissue culture. plant physiology. 15: 473-497.

[18] Al-Abasi, I. N.; M. K. Al-Mallah and Kasab Bashii B. Z. (2020). Heat shock enhancement salicylic acid biosynthesis in callus of Calendula officinalis L., J. Pharm. Sci. Res., 12: 869-874. 
[19] Larion, A.; A. Kransc and Miller W. (2005). A standard Curve based method for relative real time PCR data processing. Virtual Machine Bioinformatics. 6: 62.

[20] Koichiro, T.; S. Glen; P. Daniel; F. Alan and Sudhir K. (2013). Molecular evolutionary Genetics Analysis version 6.0 (MEGA6). Mol. Biol. Evol, 30:2725-2729.

[21] Gasteiger, E.; A. Gattiker; C. Hoogland; I. Ivanyi; R. D. Appel and Bairoch A. (2003). ExPASy: the proteomics server for in-depth protein knowledge and analysis. Nucleic Acids Res. 31:37843788 .

[22] Macar, T. K.; O. Macar and Mart D. I. (2017). Variability in some biochemical and nutritional characteristics in desi and Turkish Kabuli Chickpea (Cicer arietinum L.) Types. CBU Journal of Science. 13:677-680.

[23] Al-Whaibi, M. H. (2011). Plant heat -Shock proteins: A mini review. J. king Saud University Science, 23: 139-150.

[24] Liu, Y.; J. Li; Y. Zhu; A. Jones; R. J. Rose and Song Y. (2019). Heat stress in legume seed setting: effects, causes, and future prospects. Frontiers in Plant Science. 10:938.

[25] Fragkostefanakis, S.; S. Roth; E. Schleiff and Scharf K. D. (2015). Prospects of engineering thermo tolerance in crops through modulation of heat shock protein networks. Plant cell and Environment, 38: 1881-1895.

[26] Yona, N. (2015). Genetic characterization of heat tolerant (HT) upland mutant rice (Oryza sativa L.) lines selected from rice genotypes. Master thesis, University of Agriculture Morogoro, Tanzania.

Copyright @ 2022 Anwaar F AL-Taee, Dr. Jamella H Rasheed, AJRSP. This is an Open-Access Article Distributed under the Terms of the Creative Commons Attribution License (CC BY NC)

Doi: https://doi.org/10.52132/Ajrsp.e.2022.33.6 